\title{
Preliminary Estimate of Coal Resources in the Gillette Coalfield Affected by the Location of the Burlington Northern/Union Pacific Joint Mainline Railroad
}

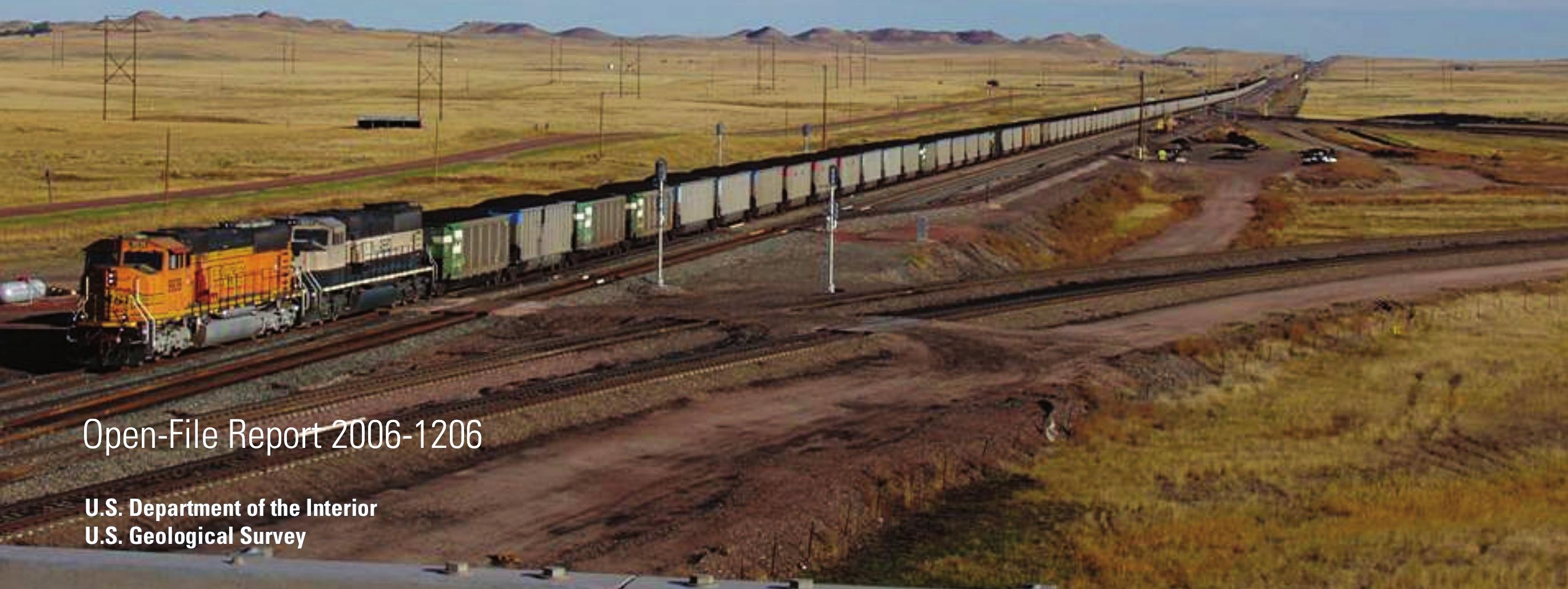


Preliminary Estimate of Coal Resources in the Gillette Coalfield Affected by the Location of the Burlington Northern/Union Pacific Joint Mainline Railroad

By Timothy J. Rohrbacher, Jon E. Haacke, David C. Scott, Lee M. Osmonson, and James A. Luppens

Open-File Report 2006-1206

U.S. Department of the Interior

U.S. Geological Survey 


\section{U.S. Department of the Interior \\ DIRK KEMPTHORNE, Secretary}

\section{U.S. Geological Survey \\ P. Patrick Leahy, Acting Director}

U.S. Geological Survey, Reston, Virginia: 2006

Posted online July 2006

This publication is available online at:

World Wide Web: http://pubs.usgs.gov/of/2006/1206

For more information on the USGS - the Federal source for science about the Earth, its natural and living resources, natural hazards, and the environment:

World Wide Web: http://www.usgs.gov

Telephone: 1-888-ASK-USGS

Any use of trade, product, or firm names is for descriptive purposes only and does not imply endorsement by the U.S. Government.

Although this report is in the public domain, permission must be secured from the individual copyright owners to reproduce any copyrighted materials contained within this report.

Suggested citation:

Rohrbacher, T.J., Haacke, J.E., Scott, D.C. Osmonson, L.M., and Luppens, J.A. 2006, Preliminary estimate of coal resources in the Gillette coalfield affected by the location of the Burlington Northern/Union Pacific joint mainline railroad: U.S. Geological Survey Open-File Report 2006-1206, 16 p. 


\section{Contents}

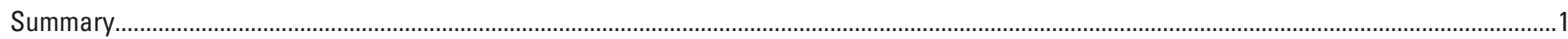

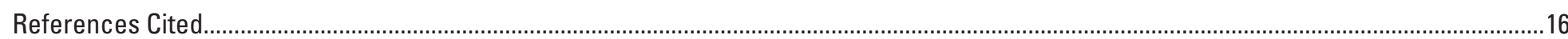

\section{Figures}

1. Burlington Northern/Union Pacific joint mainline rail service to the southern and middle mining areas (pods) of the Gillette coalfield. This photo of a unit coal train headed south was taken at the junction of the joint mainline and State Highway 450 overpass, where the Jacobs Ranch Mine and Black Thunder Mine rail loops enter the joint mainline...

2. In late 2004 the U.S. Geological Survey began a new assessment of the Gillette coalfield stratigraphy using information from many of the new coalbed methane wells that had been drilled. Coal bed correlations were modified and major mining restraints identified (Luppens, 2006). A status report was presented at the Bureau of Land Management's Regional Coal Team meeting in Casper, Wyoming on April 19, 2006 by the senior author

3. The preliminary interpretation of new data provided by recent coalbed methane exploration and development has resulted in significant changes to coal bed correlations in the Gillette coalfield. Using the newly developed geological models and pit designs presently being used in the southern and middle mining areas (pods), tonnage estimates were calculated for recoverable coal resources (the true footprint of the surface rights-of-way) that would be affected by the present location of the Burlington Northern/Union Pacific joint mainline. That footprint contains more than 1.8 billion short tons of in-place resources ...

4. Map showing the infrastructure: highways, railroads, towns, and mine locations in the Gillette coalfield area. Also shown are the geologic pods (mining areas), data location points, a portion of the paleo-Powder River channel, 500-ft-depth isopach to the top of minable coal, and the Burlington Northern/Union Pacific joint mainline location. The coal stratigraphy and coal quality are similar within each individual pod. CBM, coalbed methane.

5. Preliminary isopach map of the Anderson coal bed, which is the most important coal bed in the Gillette coalfield. It averages more than $50 \mathrm{ft}$ thick and has a maximum thickness of greater than $250 \mathrm{ft}$ north of Wright, WY. The bed is truncated to the west by the paleo-Powder River stream channel and shows the effects of at least three large east-west stream channels. Note that the thickest part of the resource is immediately west of the Burlington Northern/Union Pacific joint mainline railroad.....

6. Preliminary isopach map of the Canyon coal bed, which is the second most important coal bed in the middle and southern pods of the Gillette coalfield and lies below the Anderson coal bed. It averages more than $30 \mathrm{ft}$ thick and has a maximum thickness greater than $150 \mathrm{ft}$ north of Gillette, Wyoming. In much of the middle and southern pod area, the Canyon coal bed coalesces with the Anderson bed and is then referred to as the Anderson coal bed 
7. Preliminary Anderson coal bed isopach map for the middle and southern pods of the Gillette coalfield with north-south and east-west cross sections, mines, and area infrastructure locations. The thickest portion of the Anderson coal bed deposit lies west of the Burlington Northern/Union Pacific (BN/UP) joint mainline (in blue) from T42-T45N and R71-R74W.

8. Stratigraphic cross section incorporating information from wells drilled into the Anderson and Canyon coal beds along the joint mainline of the Burlington Northern/Union Pacific railroad. The section extends north to south across the middle and southern pods of minable coal resources in the Gillette coalfield. The average depth to the top of the Anderson coal bed and the average thickness of minable coal were determined from these coalbed methane and oil wells along the railroad rights-of-way (ROW) and substantiated by seven stratigraphic sections (locations only shown) drawn perpendicular to the joint mainline railroad right-of-way. Green color, Anderson coal bed; light blue, Canyon coal bed; dark blue, Smith coal bed; red, Felix coal bed; orange, burned zone. Coal is shown as black .....

9. This east-west cross-section across the Burlington Northern/Union Pacific joint mainline was designed using the average coal and overburden thicknesses (shown above) from the north-south stratigraphic section shown in figure 8 and from the mine planning parameters obtained from truck-shovel/dragline mines in the middle and southern pods. An average coal density of 1,770 tons/ac-ft (Wood, 1983, Fort Union Assessement Team, 1999) was obtained from U.S. Geological Survey coal quality data. Mining parameters used in the cross-section design are listed on the following slide. ROW, right-of-way......

10. Generalized pit design parameters used for the surface mine pits east and west of the joint mainline railroad rights-of-way (RR ROW) shown in figure 9. DL, dragline; TS, truck-shovel .....

11. Calculations used to estimate the coal resources affected by the Burlington Northern/Union Pacific joint mainline railroad in the middle and southern pods of the Gillette coalfield and their value shown here using a coal market sales price for the southern Gillette coalfield quoted on April 17, 2006. Cf, cubic feet; ac-ft, acre feet; sf/ac, square feet per acre

12. Estimated recoverable coal resources affected by the Burlington Northern/Union Pacific joint mainline railroad and the potential mining tax revenues from those resources

13. Some general challenges that face the coal mining industry as they plan to develop the resources west of the Burlington Northern/Union Pacific joint mainline railroad. BCY, bank cubic feet.

14. Surface restrictions to mining are generally thought to carry a small footprint or affect an area related to the surface expression With the $450 \mathrm{ft}$ of track and access road rights-of-way (ROW) required by the Burlington Northern/Union Pacific (BN/UP) joint mainline operation, the footprint on the coal resource, an average of $361 \mathrm{ft}$ below ground level, is nearly 8 times the surface reflection - without additional safety berms and benches that may be required 


\section{Preliminary Estimate of Coal Resources in the Gillette Coalfield Affected by the Location of the Burlington Northern/Union Pacific Joint Mainline Railroad}

By Timothy J. Rohrbacher ${ }^{1}$, Jon E. Haacke', David C. Scott ${ }^{1}$, Lee M. Osmonson ${ }^{1}$, and James A. Luppens ${ }^{2}$

\section{Summary}

This publication, primarily in graphic form, presents a preliminary resource assessment related to a major, near-term restriction to mining in that portion of the Gillette coalfield, Wyoming, that is traversed by the Burlington Northern/Union Pacific joint mainline railroad. This assessment is part of a current Powder River Basin regional coal assessment, including both resources and reserves, being conducted by the U.S. Geological Survey. The slides were used to illustrate a presentation of study results at a meeting of the Bureau of Land Management's Regional Coal Team in Casper, Wyoming on April 19, 2006 by the senior author.
Geologic and drilling data indicate that significant volumes of low sulfur coal resources may be bypassed by mining operations during the next 10 to 12 years. The effective footprint of the unrecoverable coal resources under the railroad corridor is much larger than previously estimated when practical mining geotechnical and safety offsets are considered. For example, the box cut required to open the coal resources west of the railroad right-of-way could have an effective mining ratio of greater than 45 to 1 (bank cubic yards overburden to recoverable tons of coal).

It is estimated that 1.7 billion short tons of recoverable coal are impacted by the 35 miles of railroad and associated access road right-of-ways. That recoverable resource represents potential Federal and State tax revenue of approximately $\$ 8.6$ billion dollars based on current (April 17, 2006) coal prices. 


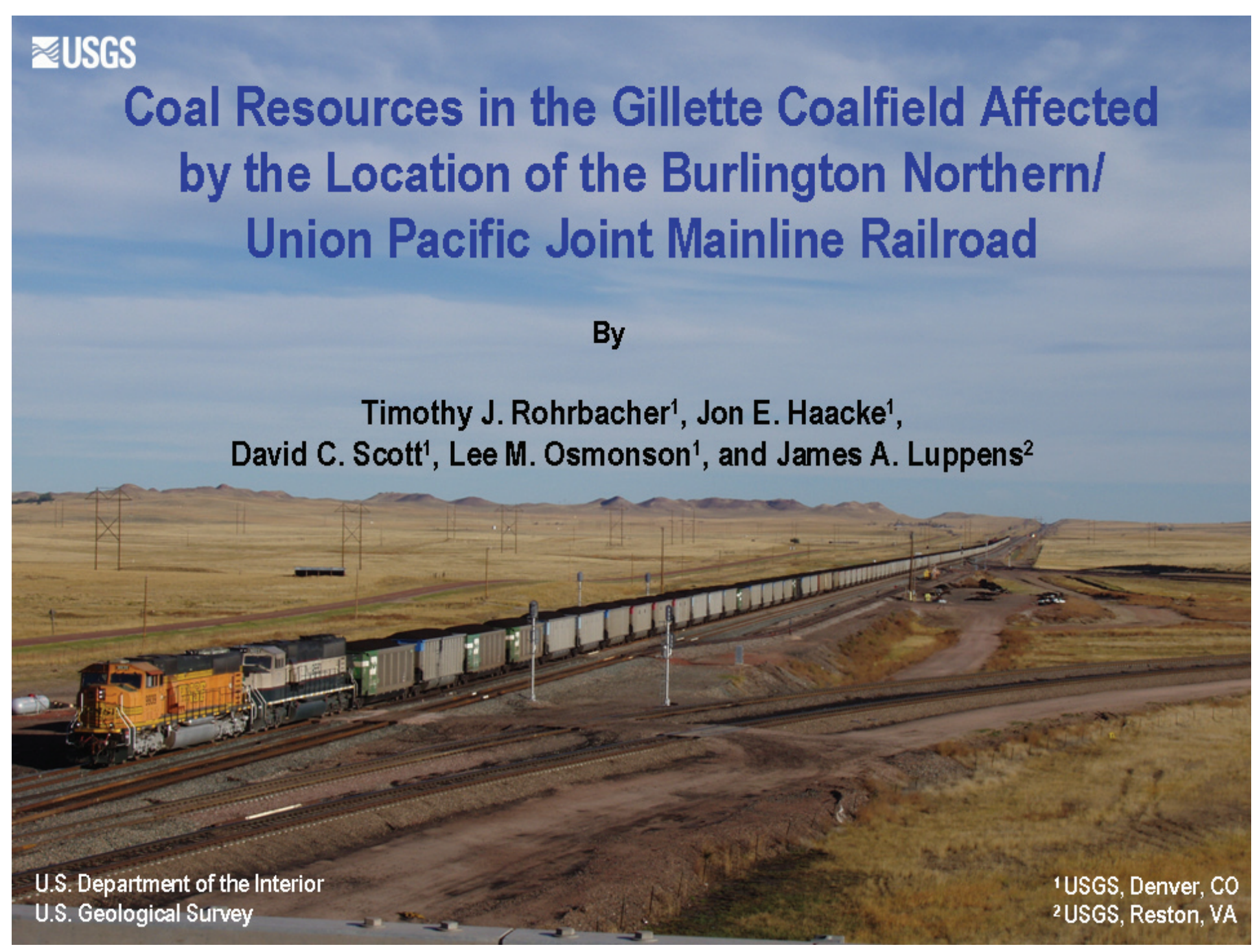

Figure 1. Burlington Northern/Union Pacific joint mainline rail service to the southern and middle mining areas (pods) of the Gillette coalfield. This photo of a unit coal train headed south was taken at the junction of the joint mainline and State Highway 450 overpass, where the Jacobs Ranch Mine and Black Thunder Mine rail loops enter the joint mainline. 


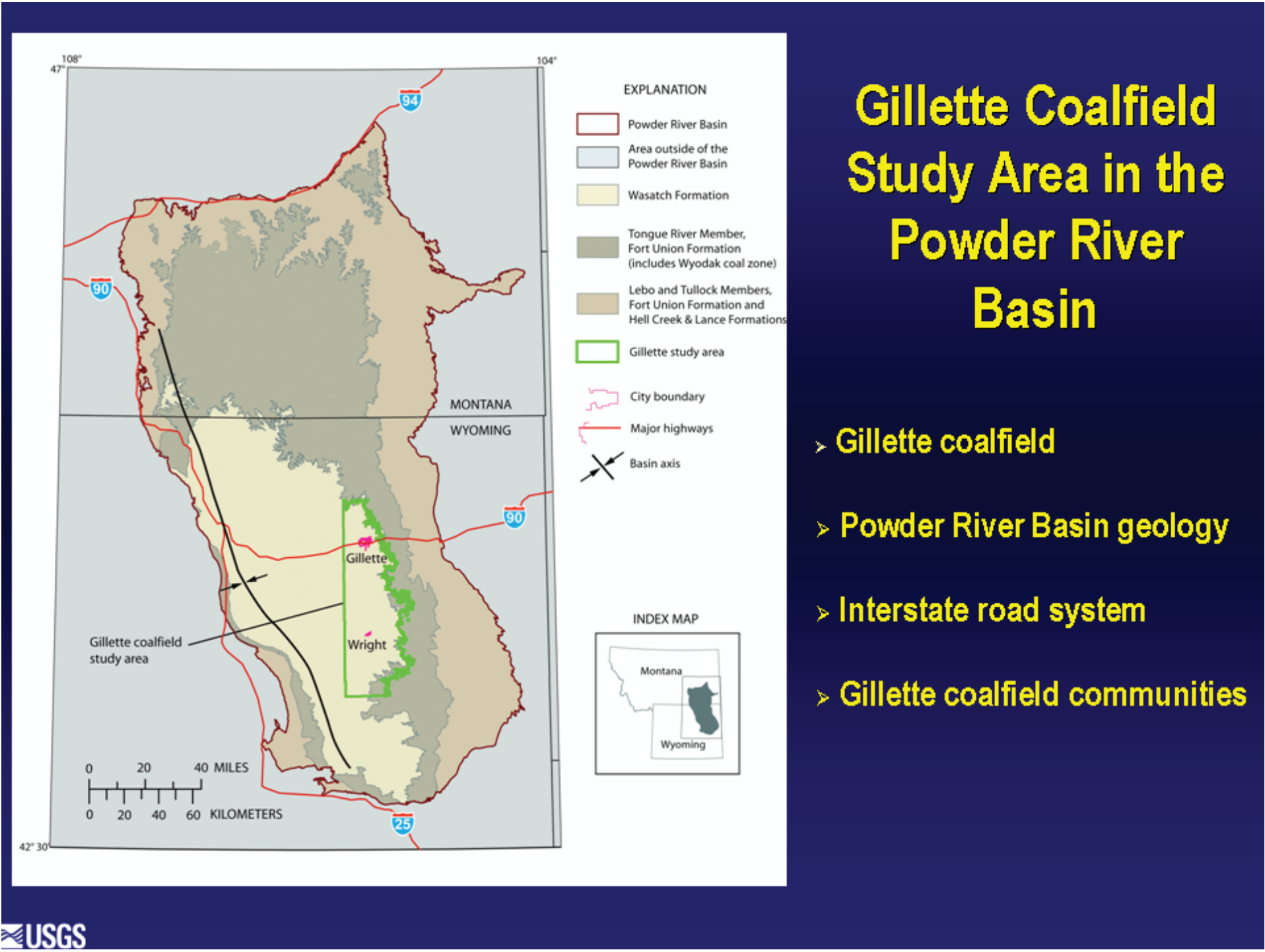

Figure 2. In late 2004 the U.S. Geological Survey began a new assessment of the Gillette coalfield stratigraphy using information from many of the new coalbed methane wells that had been drilled. Coal bed correlations were modified and major mining restraints identified (Luppens, 2006). A status report was presented at the Bureau of Land Management's Regional Coal Team meeting in Casper, Wyoming on April 19, 2006 by the senior author. 


\section{Preliminary Coal Resource Assessment Results to Date}

> Revised coal bed correlations and models have been developed for the southern, middle, and northern areas or pods of the Gillette coalfield;

- Better recognition and delineation of major sand channels in the southern and middle pods will limit long term surface mining to the west;

$\rightarrow$ A more realistic footprint of a mining restriction at depth is much greater than the surface constraints of that restriction;

- Preliminary estimates indicate that 1.8 billion tons of coal resources may be affected by the Burlington Northern/Union Pacific joint mainline railroad footprint in the southern and middle mining areas (pods) of the Gillette coalfield.

ZUSGS

Figure 3. The preliminary interpretation of new data provided by recent coalbed methane exploration and development has resulted in significant changes to coal bed correlations in the Gillette coalfield (Luppens and others, 2006). Using the newly developed geological models and pit designs presently being used in the southern and middle mining areas (pods), tonnage estimates were calculated for recoverable coal resources (the true footprint of the surface rights-of-way) that would be affected by the present location of the Burlington Northern/Union Pacific joint mainline. That footprint contains more than 1.8 billion short tons of in-place resources. 


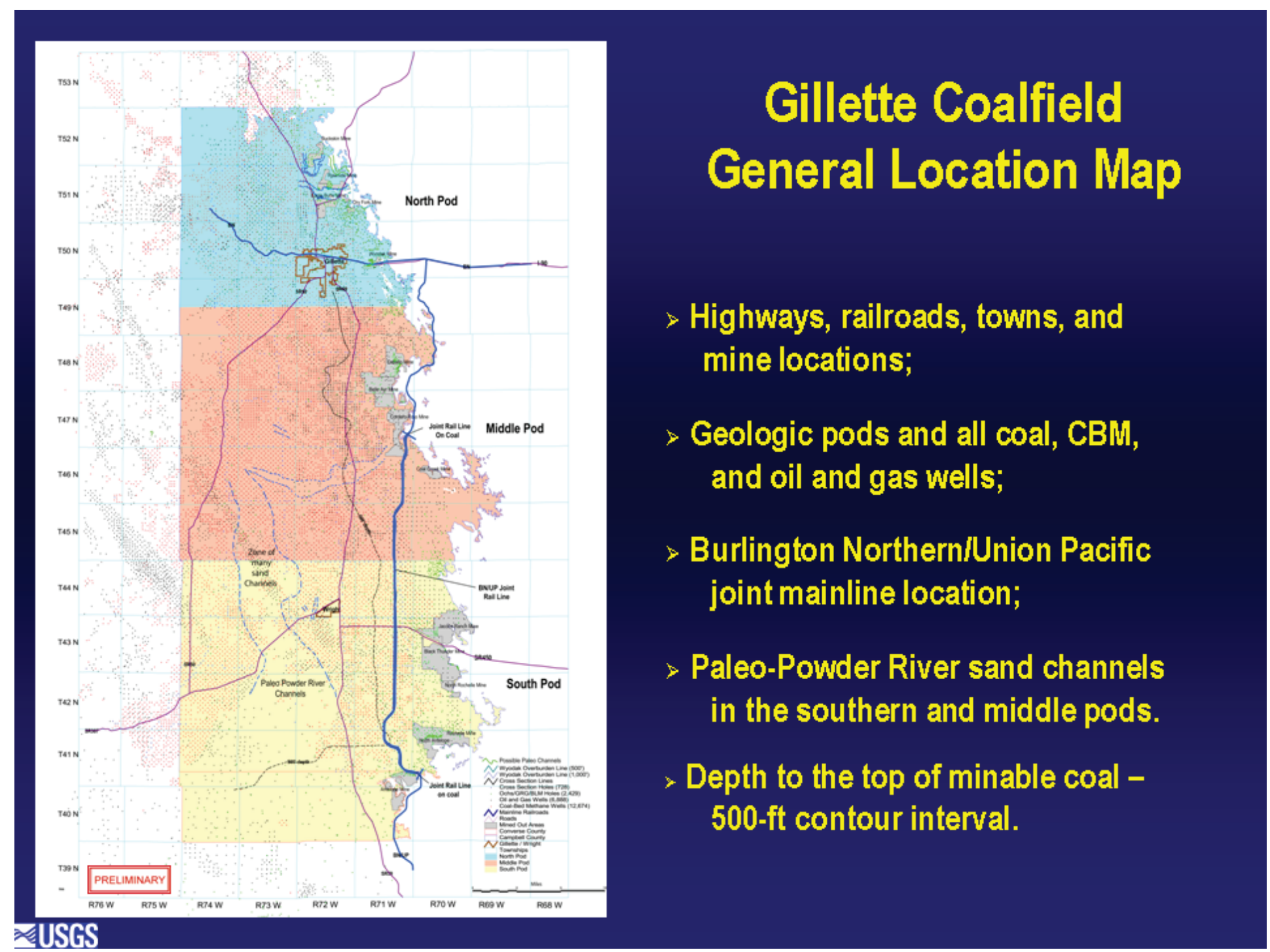

Figure 4. Map showing the infrastructure: highways, railroads, towns, and mine locations in the Gillette coalfield area. Also shown are the geologic pods (mining areas), data location points, a portion of the paleo-Powder River channel, 500-ft-depth isopach to the top of minable coal, and the Burlington Northern/Union Pacific joint mainline location. The coal stratigraphy and coal quality are similar within each individual pod. CBM, coalbed methane. 


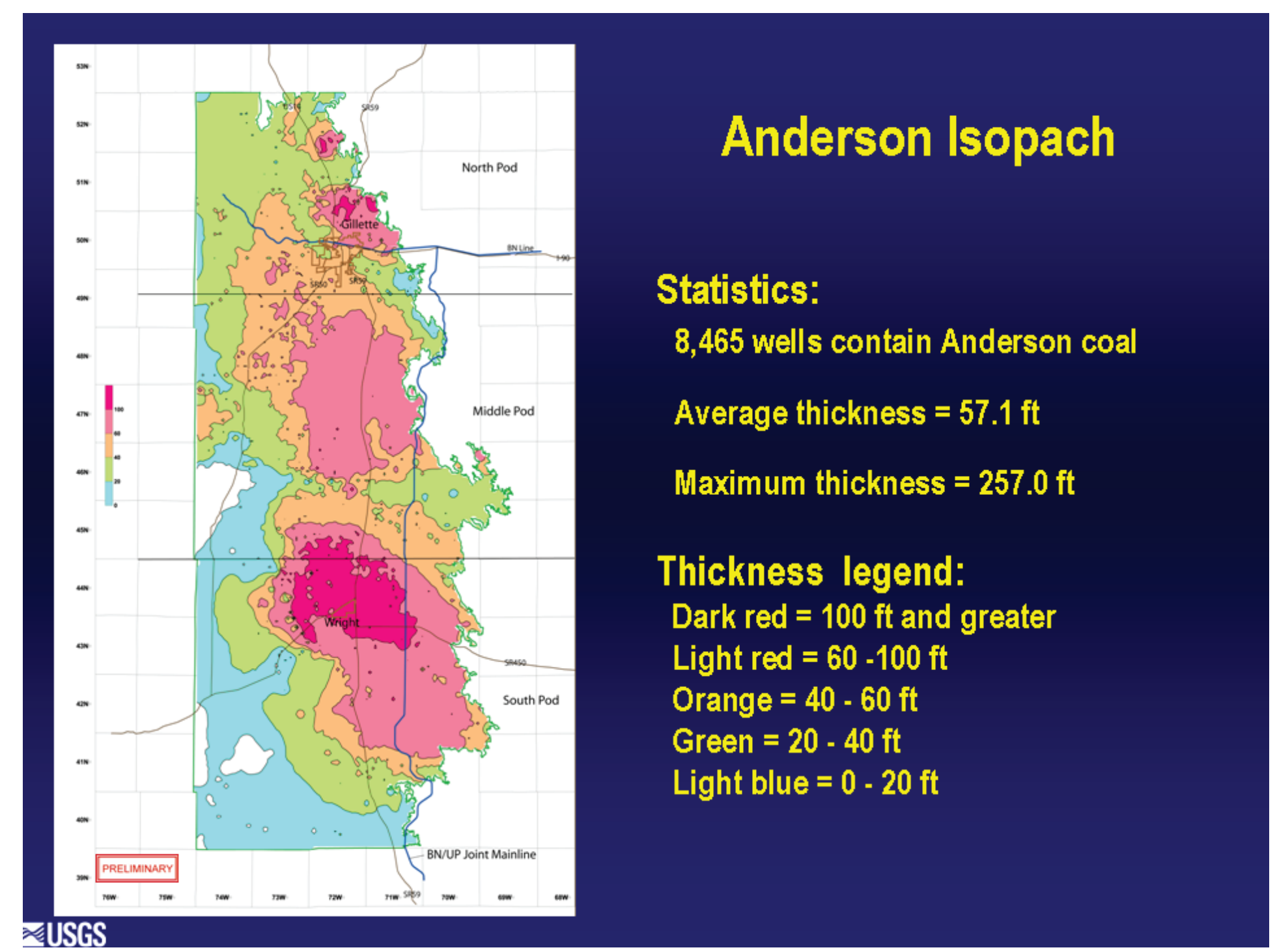

Figure 5. Preliminary isopach map of the Anderson coal bed, which is the most important coal bed in the Gillette coalfield. It averages more than $50 \mathrm{ft}$ thick and has a maximum thickness of greater than $250 \mathrm{ft}$ north of Wright, WY. The bed is truncated to the west by the paleo-Powder River stream channel and shows the effects of at least three large east-west stream channels. Note that the thickest part of the resource is immediately west of the Burlington Northern/Union Pacific joint mainline railroad. 


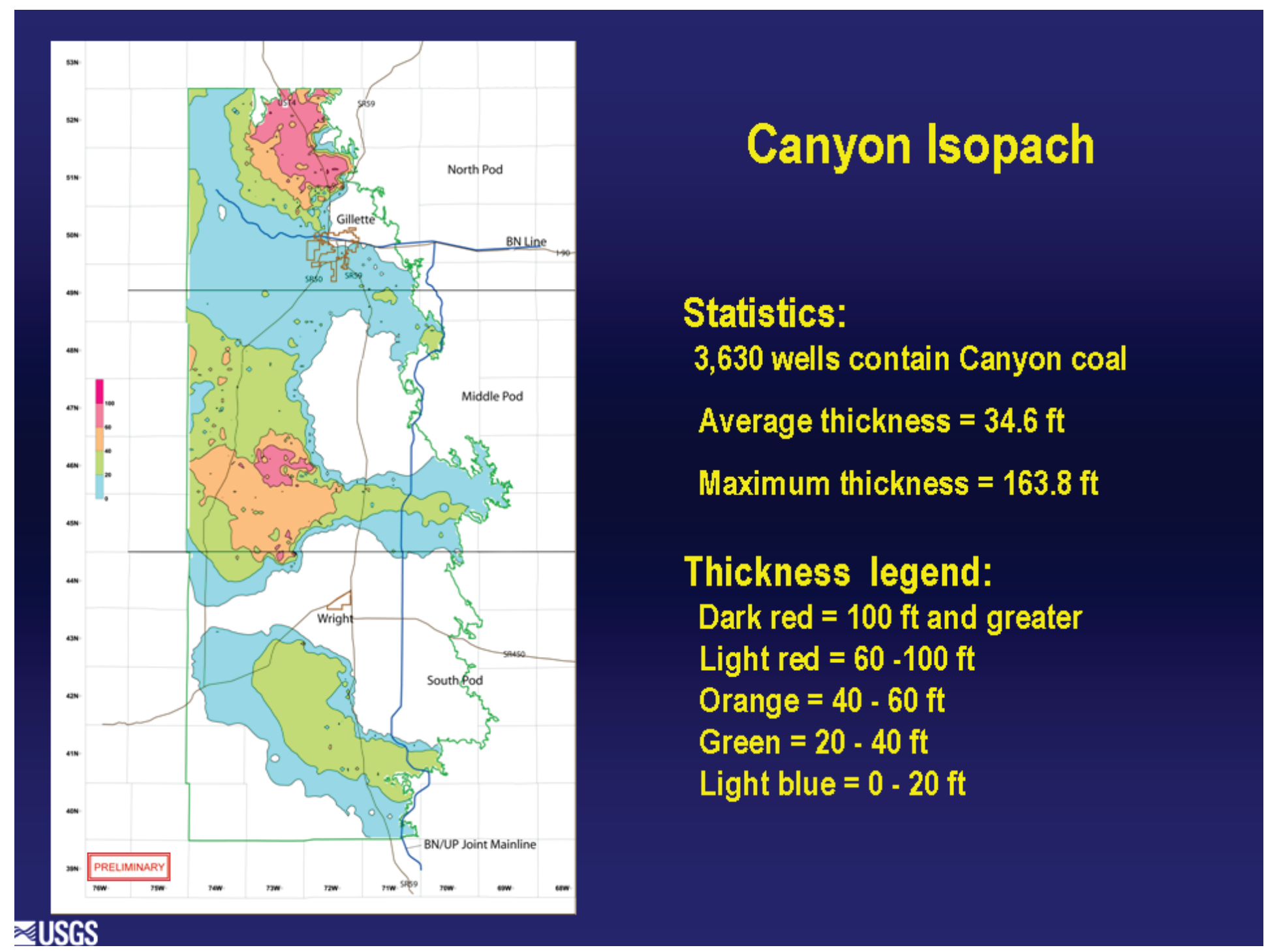

Figure 6. Preliminary isopach map of the Canyon coal bed, which is the second most important coal bed in the middle and southern pods of the Gillette coalfield and lies below the Anderson coal bed. It averages more than $30 \mathrm{ft}$ thick and has a maximum thickness greater than $150 \mathrm{ft}$ north of Gillette, Wyoming. In much of the middle and southern pod area, the Canyon coal bed coalesces with the Anderson bed and is then referred to as the Anderson coal bed. 


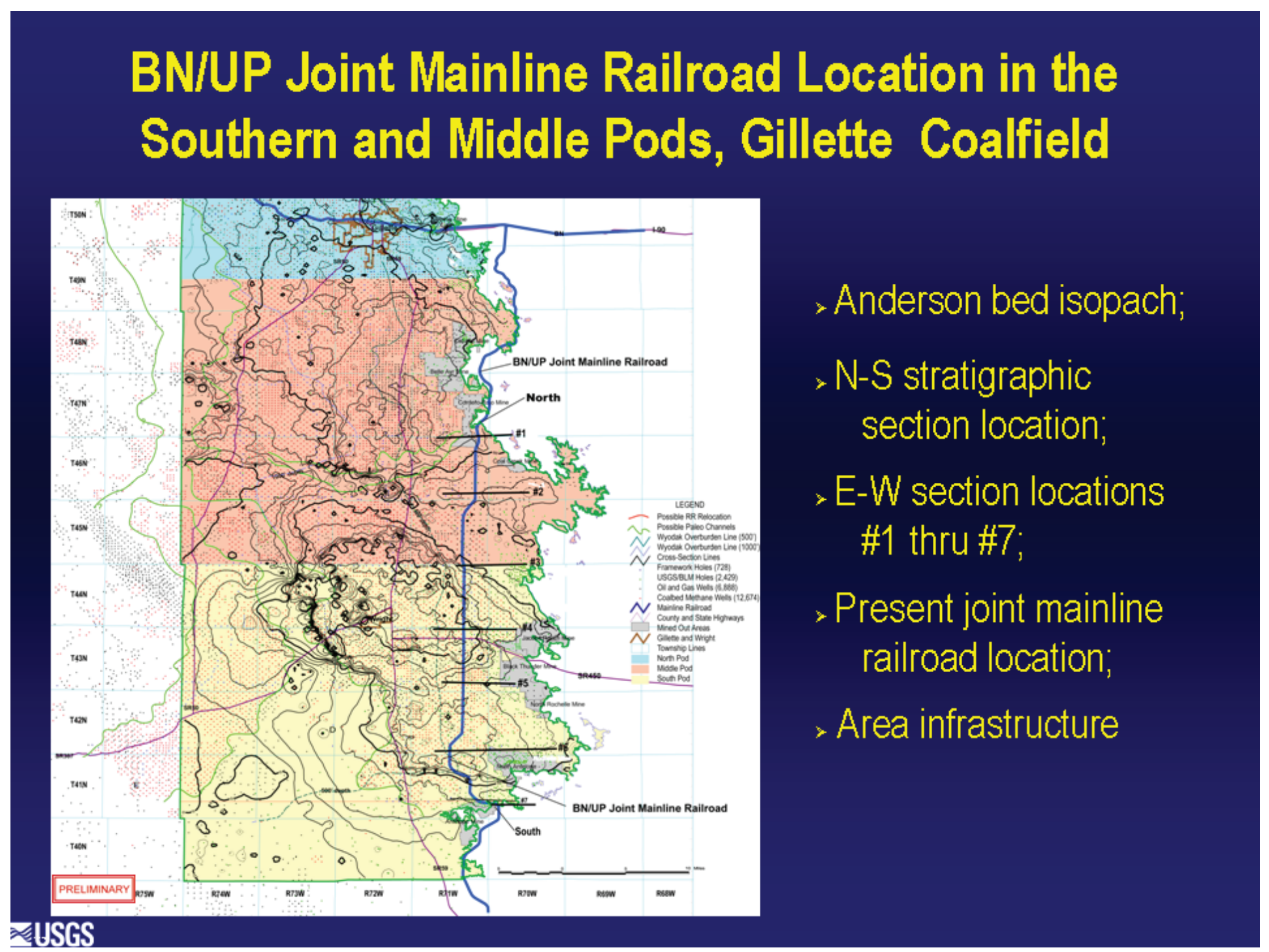

Figure 7. Preliminary Anderson coal bed isopach map for the middle and southern pods of the Gillette coalfield with north-south and eastwest cross sections, mines, and area infrastructure locations. The thickest portion of the Anderson coal bed deposit lies west of the Burlington Northern/Union Pacific (BN/UP) joint mainline (in blue) from T42-T45N and R71-R74W. 


\section{North-South Stratigraphic Section Along the Joint Mainline RR ROW - Looking East}

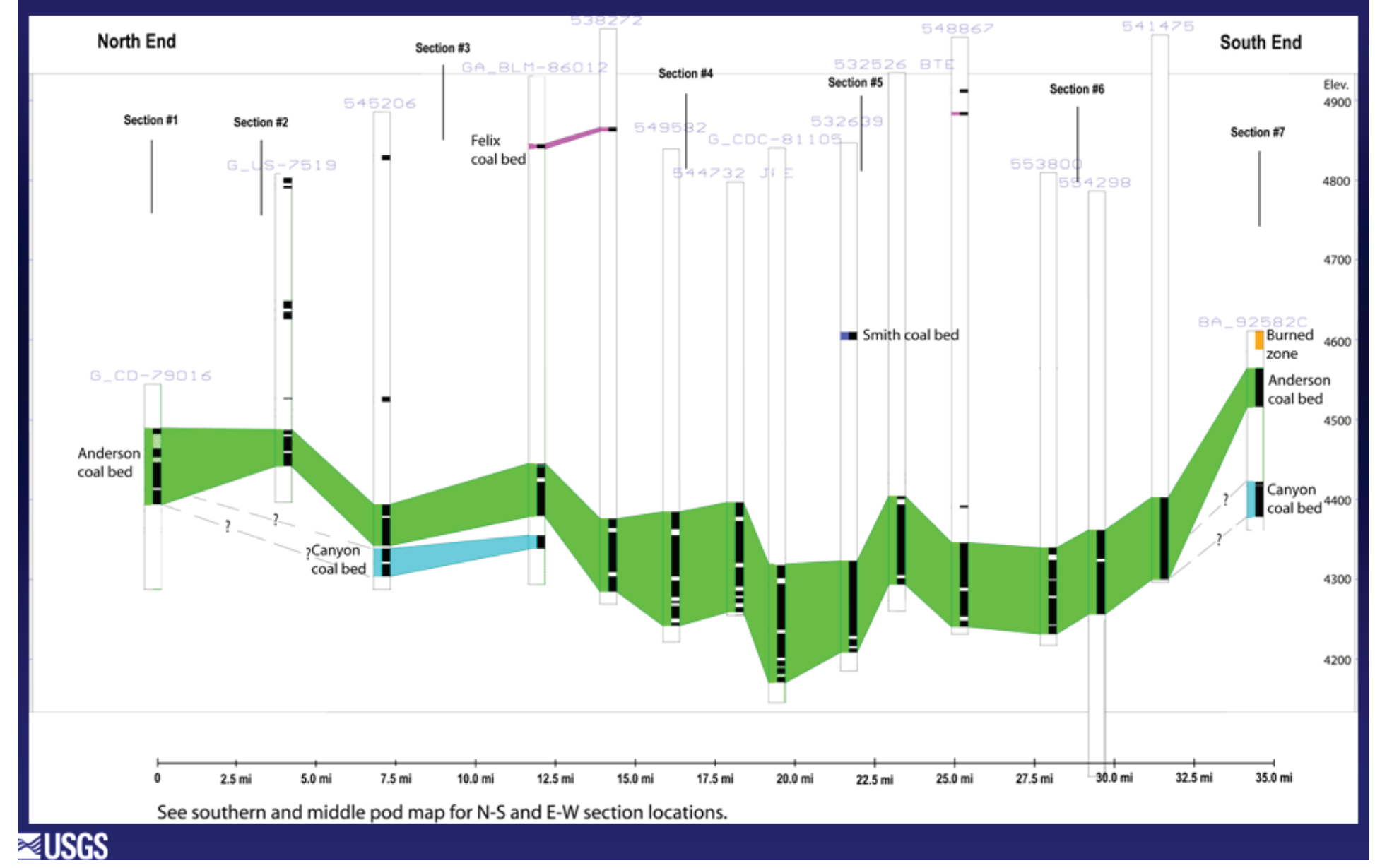

Figure 8. Stratigraphic cross section incorporating information from wells drilled into the Anderson and Canyon coal beds along the joint mainline of the Burlington Northern/Union Pacific railroad. The section extends north to south across the middle and southern pods of minable coal resources in the Gillette coalfield. The average depth to the top of the Anderson coal bed and the average thickness of minable coal were determined from these coalbed methane and oil wells along the railroad rights-of-way (ROW) and substantiated by seven stratigraphic sections (locations only shown) drawn perpendicular to the joint mainline railroad right-of-way. Green color, Anderson coal bed; light blue, Canyon coal bed; dark blue, Smith coal bed; red, Felix coal bed; orange, burned zone. Coal is shown as black. 


\section{East-West Pit Section Across Mainline Railroad and Access Road ROW}

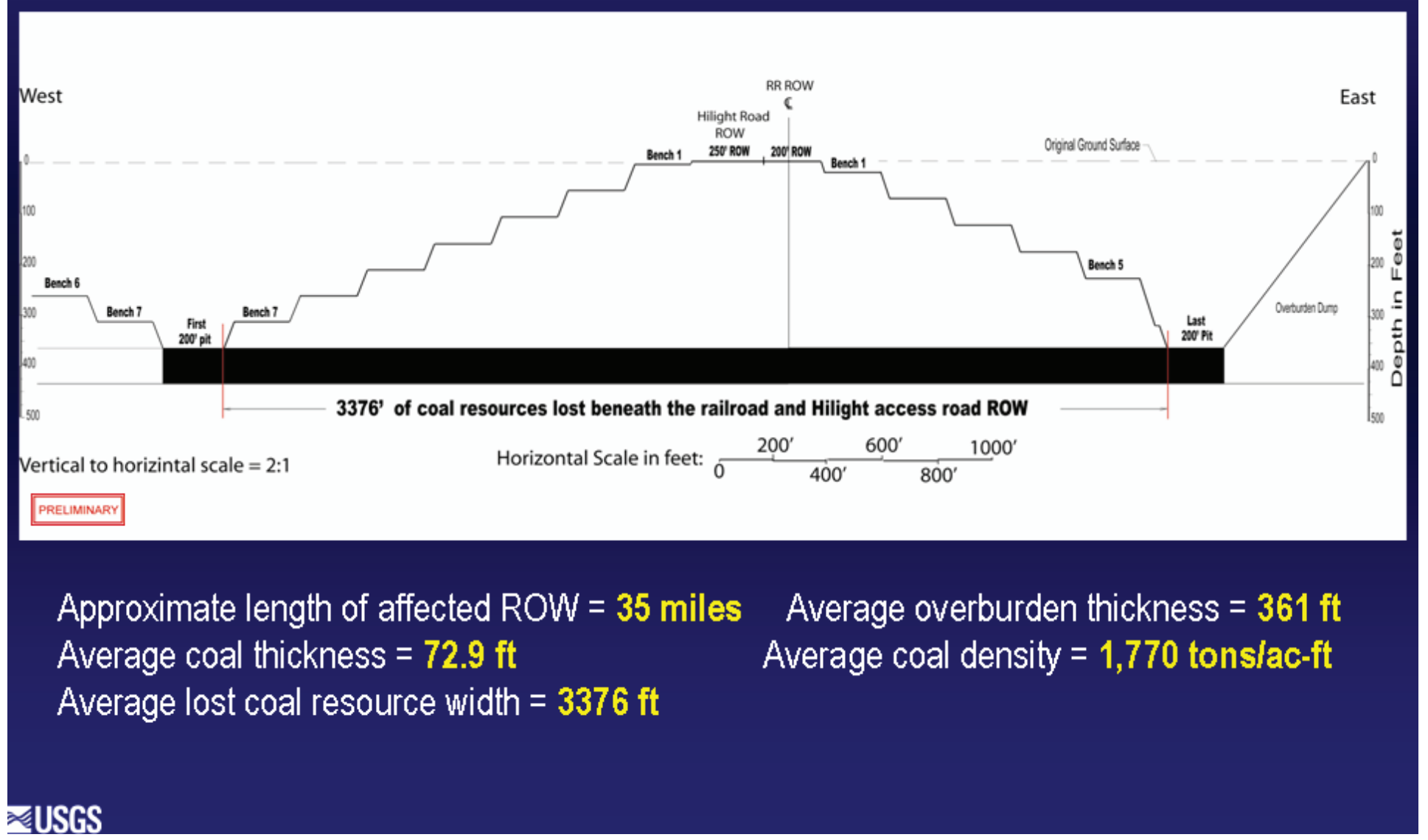

Figure 9. This east-west cross-section across the Burlington Northern/Union Pacific joint mainline was designed using the average coal and overburden thicknesses (shown above) from the north-south stratigraphic section shown in figure 8 and from the mine planning parameters obtained from truck-shovel/dragline mines in the middle and southern pods. An average coal density of 1,770 tons/ac-ft (Wood and others, 1983; Fort Union Assessment Team, 1999) was obtained from U.S. Geological Survey coal quality data. Mining parameters used in the cross-section design are listed on the following slide. ROW, right-of-way. 


\section{Mining Parameters Used for the E-W Mine Design Cross-Section in Figure 9.}

\section{East Side Pit Parameters}

> Bench widths $=200 \mathrm{ft}$

> Bench heights for TS pre-stripping $=50 \mathrm{ft}$

> Bench heights for $\mathrm{DL}$ stripping $=130 \mathrm{ft}$ or less

> Highwall angles $=55$ degrees

> Overburden dumps on the east side of the RR ROW $=35$ degree angle of repose

> 5 benches will be required to reach the top of uppermost minable coal bed

\section{West Side Pit Parameters}

> The box cut will use a TS fleet with an in-pit mobile conveyor dump to move overburden around the pit, under the RR ROW, to spreaders which will back fill the east pit

> Excess overburden from the west pit will be stored in the east pit area

> Bench widths, heights, and highwall angles are the same as the TS operation in the east side pit

- 7 benches will be required to reach the top of the uppermost minable coal bed in the west pit

\section{₹USGS}

Figure 10. Generalized pit design parameters used for the surface mine pits east and west of the joint mainline railroad rights-of-way (RR ROW) shown in figure 9. DL, dragline; TS, truck-shovel. 


\section{Calculations for the Estimated Coal Resources Affected by the BN/UP Joint Mainline Railroad}

> Length $\mathrm{x}$ width $\mathrm{x}$ coal thickness $=$ cubic feet of coal

> $(35 \mathrm{mi} \times 5,280 \mathrm{ft} / \mathrm{mi}) \times 3,376 \mathrm{ft}$ wide $\times 72.9 \mathrm{ft}=45,481,000,000 \mathrm{cf}$

> Cubic feet of coal $/ 43,560$ sflac $=$ ac-ft of in-place coal

> $45,481,000,000 \mathrm{cf}$ coal $/ 43,560$ sflac $=1,044,000$ ac-ft of coal

> Ac-ft of coal $\times 1770$ tonslac-ft $=$ tons of in-place coal

> $1,044,000$ ac- $\mathrm{ft}$ of coal $\times 1770$ tonslac- $\mathrm{ft}=1,848,000,000$ in-place tons

> 92 percent mining recovery rate $\mathrm{x}$ in-place tons $=$ recoverable tons

> $0.92 \times 1,848,000,000$ in-place tons $=1,700,000,000$ recoverable tons of resource

- Value of the coal resource $=$ recoverable tons $\mathrm{x}$ market realization at a point in time

> $1,700,000,000$ recoverable tons $x \$ 13.80$ iton $^{1}=\$ 23,460,000,000$.

\section{₹USGS}

Figure 11. Calculations used to estimate the coal resources affected by the Burlington Northern/Union Pacific joint mainline railroad in the middle and southern pods of the Gillette coalfield and their value shown here using a coal market sales price for the southern Gillette coalfield quoted on April 17, 2006. Cf, cubic feet; ac-ft, acre-feet; sf/ac, square feet per acre. 


\section{Summary of Estimated Recoverable Resources and Potential Mining Tax Revenues}

Resources and Market Value ${ }^{1}$

> Total affected coal resource

> Extractable coal resource @ 92 percent recovery

> Value of recoverable coal @ $\$ 13.80 /$ ton $^{1}$

$=\quad 1,848,000,000$ tons

$=1,700,000,000$ tons

$=\$ 23,460,000,000$

Estimated State and Federal Taxes

> Federal royalty @12.5\% Rate

> Federal lease bid @ \$1.00iton

$=\$ 2,932,000,000$

>Black lung tax @ \$0.55/ton

> Reclamation tax @ \$0.35/ton

> State severance tax @ $\$ 0.60 /$ ton

> State ad valorum tax @6.0\%

> Total federal and state taxes ${ }^{2}$

$=$

$=$

$=$

$=$

$=$

$=$
$\$ 1,700,000,000$

$\$ 935,000,000$

$\$ 595,000,000$

$\$ 1,020,000,000$

$\$ 1,408,000,000$

$\$ 8,590,000,000$

\section{‡USGS}

Figure 12. Estimated recoverable coal resources affected by the Burlington Northern/Union Pacific joint mainline railroad and the potential mining tax revenues from those resources. 


\section{Challenges Facing Mine Construction West of the Burlington Northern/Union Pacific Joint Mainline Railroad}

> The long range mine plans of several mining operations show the need to begin coal production under or west of the BN/UP joint mainline within a 10-to 12-yr time frame at the present rate of extraction

> National energy reports estimate the need for increased coal production to continue into the next two decades. Much of that forecasted increase in production will be from the southern and middle pods of the Gillette coalfield (National Coal Council, 2006)

> It is estimated that the lead time to open a box cut for coal production west of the railroad corridor may require more than 5 years from the end of coal leasing and mine permitting due to the availability of mining equipment, infrastructure construction, and pre-stripping operations

- Assuming that the mining methods will be similar to the present pre-stripping operations, the box cut ratio will be in excess of $45: 1$ (BCY overburden: tons recoverable coal)

> Stripping shovel fleets will have to be increased to an appropriate level to handle the increased amount of overburden (perhaps 10 times the number of shovels) and the time line for stripping from surface to the coal will be in years rather than months

₹USGS

Figure 13. Some general challenges that face the coal mining industry as they plan to develop the resources west of the Burlington Northern/Union Pacific joint mainline railroad. BCY, bank cubic feet. 


\section{Resources Affected by the BN/UP Joint Mainline Railroad - Summary}

> The area affected by the BN/UP and associated access road ROWs affects a much larger footprint than originally thought and affects a significant amount of southern Gillette coalfield resource. For example, the joint mainline was shown as a restriction with $300 \mathrm{ft}$ buffers on each side of the ROW in the 2002 Gillette coalfield resource evaluation (Ellis, and others, 2002, p. 34);

- Many challenges to sustained coal production in the southern Gillette coalfield will be encountered with the excavation of new box cuts west of the joint mainline railroad;

> Total coal resources affected by the BN/UP joint mainline location are: $1,848,000,000$ in-place tons, market value ${ }^{1}=\$ 23,460,000,000$, and the estimated State and Federal coal mine tax revenues ${ }^{2}=\$ 8,590,000,000$.

Figure 14. Surface restrictions to mining are generally thought to carry a small footprint or affect an area related to the surface expression. With the $450 \mathrm{ft}$ of track and access road rights-of-way (ROW) required by the Burlington Northern/Union Pacific (BN/UP) joint mainline operation, the footprint on the coal resource, an average of $361 \mathrm{ft}$ below ground level, is nearly 8 times the surface reflection - without additional safety berms and benches that may be required. 


\section{References Cited}

Ellis, M.S., Molnia, C.L., Osmonson, L.M., Ochs, A.M., Rohrbacher, T.J., Mercier, Tracey, and Roberts, L.N.R., 2002,

Evaluation of economically extractable coal resources in the Gillette Coalfield, Powder River Basin, Wyoming: U.S. Geological Survey Open-File Report 2002-180, http://pubs. usgs.gov/of/2002/ofr-02-0180.

Fort Union Coal Assessment Team, 1999, 1999 Resource assessment of selected Tertiary coal beds and zones in the Northern Rocky Mountains and Great Plains Region: U.S. Geological Survey Professional Paper 1625-A, 2 CDROMs.

Luppens, J.A., Rohrbacher, T.J., Haacke, J.E., Scott, D.C., and Osmonson, L.M., 2006, Status Report: USGS Coal Assessment of the Powder River, Wyoming: U.S. Geological Survey Open-File Report 2006-1072, http://pubs.usgs. gov/of/2006/1072\%

National Coal Council, 2006, Coal: America's Energy Future: National Coal Council, Thomas G. Kraemer, chair, v. 1, $125 \mathrm{p}$.

Platts, 2006, Coal Outlook: 3333 Walnut Street, Boulder, CO, v. 30, No. 16, http://www.platts.com.

Wood, G.H., Jr., Kehn, T.M., Carter, M.D., and Culbertson, W.C., 1983, Coal resource classification system of the U.S Geological Survey: U.S. Geological Survey Circular 891, $65 \mathrm{p}$. 